\title{
Claiming Sacred Ground: A Spatial Practice
}

\author{
With Martin Hoondert
}

It is 8:30 PM on Maundy Thursday, three days before Easter. Welcome to Rotterdam! A world-class city where one can find the colourfulness of our country in every street. But also a city that took a major role in a history of suffering, destruction, death and reconstruction [WWII, $\mathrm{MK}$. A city that, like no other, understands and feels the impact of the age-old and world-famous narrative of suffering, death and resurrection. Tonight, Rotterdam forms the stage for The Passion. (...) The streets of this metropolis are our Jerusalem.

NARRATOR PHILIP FRERIKS, 5 April 2012

(Willem Square, Rotterdam)

Over the years, The Passion has travelled from one city to another: this popular retelling of the last hours of the life of Jesus of Nazareth is an event that has moved across time and space. ${ }^{1}$ Using the ideas of Thomas Tweed, we might say that time and again the Passion has found a temporary dwelling in a particular practice performed by particular people in a particular place. Indeed, every year, another large city is for one night transformed into first-century Jerusalem, with significant locations within the city forming the decor for various scenes in the narrative. The sense of anticipation before the performance commences is always palpable in that place, with giant screens set up in the main square counting down the minutes and seconds until it begins. City governments lobby heavily to bring the event to their square and, once the die is

1 This chapter is partly based on an article previously published as Martin Hoondert and Mirella Klomp, "The Streets of Gouda", in Sacred Spaces and Contested Identities. Space and ritual dynamics in Europe and Africa, ed. Paul Post, Philip Nel and Wouter van Beek. (Trenton, NJ: Africa World Press, 2014), 313-33o. Author's contributions in this chapter are as follows: I wrote the text of all sections, with the exception of 'The Passion as spatial practice', which is based on Hoondert's work and was revised by me for the purpose of publication in this book. 
cast, spend months building up to the big moment. In the weeks beforehand, shop owners change their window displays to feature large white cardboard crosses to help promote their merchandise, local bars and cafes offer "Last Supper" special menus that all feature bread and a red drink of some sort. Local churches, city authorities, schools and universities plan and host multiple side events. National television and newspapers are filled with discussion and commentary about the event in the days leading up to it. It seems as though every year the Passion of Jesus truly takes over a city and the entire country.

On the stage, which is often built on city squares normally used for a variety of events (among other things, markets with food or clothes stalls), the narrator uses the opening sentences to connect the ritual-musical performance of this Christian narrative to a particular locality. The repetition of this explicit connection by the subsequent narrators of The Passion draws the attention to The Passion as a localised and spatial practice. The structuring elements of the network society - mobility, communication technology, globalisation and relocation (see the discussion of Appadurai's -scapes in Chapter 2) might lead us to think that space and place have become irrelevant. However, late-modernity, with its flux and flow, its dynamics and fluidity, transforms our relationship to space and place, and thus requires that these notions are rethought. Academics in various disciplines have risen to the occasion: in both the humanities and the sciences, particularly since the late zoth century, scholars have rediscovered space and place as a research subject, to the extent that this trend has been defined as a 'spatial turn'.2 At the intersections of space and/or meaning, sacrality, religiosity and ritual, important research has been done by historian Mircea Eliade (1907-1986), philosophers Michel Foucault (1926-1984) and Henri Lefebvre (1901-1991), political geographer Edward Soja (1940-2015), Jonathan Z. Smith (1938-2017), and ritual studies scholars Ronald L. Grimes ( $\left.{ }^{*} 1943\right)$ and Paul Post $\left({ }^{*} 1953\right) .{ }^{3}$ Post, in particular, has argued that a

2 See Sigurd Bergmann, "Theology in its Spatial Turn: Space, Place and Built Environments Challenging and Changing the Images of God", Religion Compass 1, no. 3 (2007), 353-379.

3 A useful overview can be found in Kim Knott, The Location of Religion. A Spatial Analysis (London: Routledge, 2005), in which the author locates religion within the social, cultural and physical spaces of the present, using a method informed by the spatial theory of Lefebvre in particular. It is worth mentioning just a few other publications here: Mircea Eliade, The Sacred and The Profane. The Nature of Religion (London: Harcourt Brace Jovanovich, 1987); Michel Foucault, "Of Other Spaces, Heterotopias", Translated from Architecture, Mouvement, Continuité 5 (1984), 46-49; Henri Lefebvre, The Production of Space (Oxford/Cambridge: Wiley-Blackwell, 1991) (original edition published in French in 1974); Edward W. Soja, Thirdspace. Journeys to Los Angeles and Other Real-and-imagined Places (Malden (Mass.): Wiley-Blackwell, 1996). Jonathan Z. Smith, To Take Place. Toward Theory in 
changing post-Christian world requires a new perspective on religion, rituality and sacredness. In his own research, he is particularly alive to the repertoire of actions that occur in new places, as well as the role of spatial context as a factor in people's processes of meaning-making. ${ }^{4}$ He has also supervised a number of $\mathrm{PhD}$ projects that empirically investigate the sacred in ritual repertoires in new places. ${ }^{5}$ However valuable and insightful, these studies do not discuss the respective rituals from a theological perspective. In this chapter, we will focus on The Passion as a ritual-musical passion performance that has moved into and occurs within the (secular) public sphere, investigating it as a spatial practice.

The localised practice of The Passion, as emphasised by the narrators, understood against the background of the spatial turn, leads us to formulate the following question: how does the spatial practice of a Christian ritual form in a city square turn this square into a sacred place? The Gouda edition of The Passion in 2011 will serve as a specific case in this chapter. We will first discuss some core concepts, and then interpret The Passion as a spatial practice in which physical, ritual, and musical spaces come together. As the stage for this Christian-rooted multimedia event was erected in the public space, it obviously takes place, in some sense, on contested ground, and our attention in fieldwork was drawn to diverging appropriation of this practice. In conclusion, we will, therefore, expand on the complexity and ambiguity of the sacralising of public space in a secularised context.

Ritual (Chicago: University of Chicago Press, 1992). Ronald L. Grimes, Rite out of Place: Ritual, Media and the Arts (Oxford: Oxford University Press, 2006), esp. 101-116; Paul Post and Arie Molendijk, eds., Holy Ground. Re-inventing Ritual Space in Modern Western Culture (Leuven: Peeters Publishers, 2010); Paul Post, Philip Nel and Walter van Beek, eds., Sacred Spaces and Contested Identities. Space and ritual dynamics in Europe and Africa (Trenton: Africa World Press, 2014).

4 Cf. his fields of the sacred as discussed in the prologue and the transfer of a 'basic sacral' attitude and behaviour to various domains in chapter 2 .

5 Juchtmans, Rituelen thuis; Judith Tonnaer, Bomen voor het leven: Een studie naar een hedendaags collectief herdenkingsritueel voor overleden kankerpatiënten, Netherlands Studies in Ritual and Liturgy 11 (Groningen/Tilburg: Instituut voor Liturgiewetenschap/Instituut voor Rituele en Liturgische Studies, 2010); Logan Sparks, Ambiguous Spaces. A Contextualisation of Shared Pilgrimage in Ephesus (PhD thesis, Tilburg School of Humanities s.l., 2011); Schippers, Sacred places in the suburbs; Laurie Faro, Postponed monuments in the Netherlands. Manifestation, context, and meaning (PhD thesis, Tilburg School of Humanities s.l., 2015). Martijn de Ruijter, Confining frailty. Making place for ritual in rest and nursing homes, Netherlands Studies in Ritual and Liturgy 18 (Groningen/Amsterdam: Institute for Christian Cultural Heritage/Instituut voor Rituele en Liturgische Studies, 2016). Wijnia, Making Sense; Suzanne van der Beek, New Pilgrim Stories: Narratives, Identities, Authenticity (PhD thesis, Tilburg School of Humanities s.l., 2018). 


\section{Space, Place and the Sacred}

Space and place are often used as interchangeable notions, but can, nevertheless, be distinguished. Generally, theoretical distinctions between space and place boil down to space being considered as more abstract, while place is taken as a specific location created by human experiences. ${ }^{6}$ Space offers a condition for anything that exists, while place exists when space is filled with meanings and objectives by human experiences that are particular to this space. ${ }^{7}$ Space and place are inextricably related, which may be the reason why they are not always distinguished and are often used in the same breath. However, in this case, we clearly recognize that The Passion is performed in the public domain (space) and, more specifically, in the market square in Gouda (place).

The notion of 'the sacred' has been the subject of strong debates in religious studies and theology for over a century. Lieke Wijnia in her PhD thesis on the sacred in music thoroughly discusses a wide range of viewpoints, pointing, among other things, to two fundamentally different approaches, one substantive (referring to the sacred as a powerful manifestation of reality) and one situational (recognising that nothing is inherently sacred). ${ }^{8}$ The latter approach has a long tradition of describing 'the sacred' as 'set apart', thus relating the sacred to the human activity of interpretation. ${ }^{9}$ Sociologist Emile Durkheim, for example, in his definition of religion, singled out the quality of being 'set apart' as a defining feature: "A religion is a unified system of beliefs and practices relative to sacred things, that is to say, things set apart and forbidden.... ${ }^{10} \mathrm{He}$ emphasised the significance of human action, connecting sacrality to consecrating actions. ${ }^{11}$ Almost a century after Durkheim launched his theory, Gordon Lynch proposed a reinterpretation of it, criticising Durkheim's

6 Cf. e.g. philosopher Yi-Fu Tuan, Space and Place: The Perspective of Experience (Minneapolis: University of Minnesota Press, 1977); or geographer Edward Relph, Place and Placelessness, 14th ed. (Los Angeles (CA): Sage, 2016).

7 Tuan, Space and Place, 4.

8 Cf. Wijnia, Making Sense, 31-48. Post has argued that the opposition between substantialists (/essentialists) and situationalists should not be exaggerated. Cf. Paul Post, "Complexity and conflict. The contemporary European church building as ambiguous sacred space", in Post, Nel and Van Beek, Sacred spaces and contested identities. 241-265, here 243. Wijnia, Making Sense, 33 .

10 Durkheim, The Elementary Forms, 47. On the 'set apart', also see Matthew Evans, "The sacred. Differentiating, clarifying, and extending concepts", Review of Religious Research 45, no. 1 (2003), 32-47.

11 See Schippers, Sacred places in the suburbs, 6o, where she writes that the act of sacralising may be extended from the concept of religion to sacred places and objects. 
radical separation of the sacred and the profane, and his tendency to substantialize the sacred by assuming that the power and significance of the sacred derives from the human experience of participating in the self-transcending reality of the social group. ${ }^{12}$ Rejecting this ontological claim, Lynch nevertheless maintains Durkheim's assertion "that the radical otherness of sacred forms is experienced by their adherents as non-contingent - an absolute reality that stands over and above the mundane, contingent nature of everyday life". ${ }^{13}$ Regarding Durkheim's classification of 'sacred things' as things set apart, Wijnia notes that, in ethnography studying the sacred, the researcher should distinguish between 'things that are set apart' and 'the process of setting apart', the latter being not only a physical but a mental process. ${ }^{14}$

When it comes to the triad space/place - ritual - sacrality/religion, both Jonathan Z. Smith and Grimes, similarly depart from the (situational) approach that sacrality is not inherent to a particular place or object. Yet each of them soon goes his own way, to a different end of the spectrum. Smith asserts that "Sacrality is, above all, a category of emplacement", while Grimes maintains that the ritual performance or act is decisive in making a space/place sacred. ${ }^{15}$ Grimes even explicitly states that "Sacrality is not a quality of places, it comes and goes depending on the way people act, what they say, and how they feel about the specific place". ${ }^{16}$ Empirical studies often show that the theoretical distinctions are not as sharp as assumed: what takes precedence in the process of sacralising (place or gesture) probably differs from one case to another. ${ }^{17}$

With these scholars, we take the sacred as a label that people (individually or collectively) can attach to a specific place, either because the place calls forth ritual performances or gestures, or because ritual performance/gesture occurs in a specific place that thereby becomes sacred. The (situational) approach seems to us to be particularly suitable in late-modern societies

\footnotetext{
12 Lynch, The sacred in the modern world, 26.

13 Lynch, The sacred in the modern world, 26.

14 Wijnia, Making Sense, 41.

15 Smith, To Take Place, 104; Ronald L. Grimes, "Jonathan Z. Smith's theory of ritual space", in Religion 29 (1999), 262-273.

16 Schippers, Sacred places in the suburbs, 61. The information on Grimes' view was derived from a personal email he wrote to Schippers on December 12, 2010.

17 Post and Molendijk, "Introduction", in Holy Ground, eds. Post and Molendijk, 1-13, here 8. Eric Venbrux in his contribution to that edited volume convincingly asserted that it works both ways: "the gesture can make the place sacred, and a sacred place provokes the gesture". Eric Venbrux, "Ritual Space and Ritual Gesture. Three types of ritual communication in throwing coins into the water", in Holy Ground, eds. Post and Molendijk, 301-312, here 312 .
} 
where processes of meaning-making and of valuation have changed. As liturgical scholar Marcel Barnard has claimed, in line with the theory of Manual Castells:

late modern society is characterized by a 'plural authority structure'. Power and authority are divided, and to a considerable extent lie with individuals, small groups or interest groups that express themselves through ubiquitous networks. This also holds for the authority by which particular events or texts are being interpreted. (...) People compose their own religious life, if so desired. ${ }^{18}$

Indeed, whether things are sacred or not depends on whether or not these things are subjected to sacralising practices. The sacred is a result of the human activity of interpretation: sacrality is in the eye of the beholder. In the public sphere, this means trouble, as Smith also emphasizes, "sacred places should be seen as arenas in which the balance of power is constantly switching between insiders and outsiders, rulers and followers, old and young people, men and women. Sacred space is contested space." ${ }^{19}$

\section{The Passion as Spatial Practice}

The opening sentences and the performance of The Passion that followed turned Gouda, for a period, into the holy city of Jerusalem, where the final hours of Jesus' life took place. Now that we defined some significant notions and relations, we will turn to address the question of how, in the market square in Gouda, this spatial practice worked - or how, with reference to the title of a book by Henri Lefebvre, space was 'produced' by the performance of The Passion. ${ }^{20}$ This will help us better understand the next section, where we discuss how this sacred space could (or could not) become both sacred, and contested at the same time. In his book, Lefebvre suggests that place never acquires a

18 Marcel Barnard, "Bijbellezen als textiele werkvorm. 'O Meester, Slaaf en Broeder, Geslachte en Verrezen God'”, Schrift. Tijdschrift over de Bijbel 270, 46, no. 1 (2014), 30-34, $3^{1}$ (translation by Klomp). Cf. also Barnard, Cilliers and Wepener, Worship in the network culture, 77. Barnard takes 'plural authority structure' from Manuel Castells, The information Age 2. The Power of Identity (Oxford: Blackwell Publishers Ltd, 1997/2004). Castells quotes David Held, "Democracy, the nation-state and the global system", in Economy and Society 20, no. 2 (1991), 138-172 at 161-167.

19 Schippers, Sacred places in the suburbs, 62.

20 Lefebvre, The production of space. 
definitive shape, but is always on the move: place is actively produced, and is therefore never abstract or passive. The meaning a place has is meaning that comes into being in what he calls 'spatial practice': the ways in which people generate, use, and perceive space. Meaning accordingly develops in doing, on the one hand, and in understanding and experiencing, on the other. Attribution and appropriation are both encompassed in spatial practice. ${ }^{21}$ We identify four (different, though related) aspects: physical, ritual, musical and mental space. Throughout these spaces, the event is also inevitably a social space.

\section{Physical Space}

When reflecting on The Passion as spatial practice, we firstly find that the performance took place in a physical space. The city centre of Gouda is old and has many historical buildings. The market square, where the town hall, which dates back as far as 1459, is located forms the heart of the city centre. Very close to this market square, we find the large gothic Sint Jan church with its famous stained-glass windows. Furthermore, Gouda is a city known for its cheese and its candle makers. This typically Dutch place serves as the stage for an age-old biblical narrative. For the duration of the performance (maybe we should also include installation and dismantling of the stage), the city is taken over by the makers of The Passion. The market square is staked out for the audience, actors and orchestra, and the streets of Gouda are claimed by a procession carrying a big, fluorescent cross. For the duration of the event, a total of go minutes, TV viewers find themselves transported to Gouda and the market square, and participate in the event (either in real time, or afterwards through the internet).

\section{Ritual Space}

The Passion is also a highly ritualised performance that turns the city into a ritual space, in which the story of Jesus is told, sung and portrayed. This ritual action, song and speech are goal-oriented, with the aim of 'claiming' physical space so that the city will become 'saturated' with meaning, and the centre of Gouda does indeed become a sacred space. The ritualised space of the city centre is therefore inherently also a politicised space, as the organisers of The Passion intentionally make the passion narrative part of a public sphere in which religion is often considered to belong 'behind the front door'.22 As much

\footnotetext{
21 Cf. Post and Molendijk, Holy Ground.

22 Cf. Irene Stengs, "Public practices of commemorative mourning" in Holy Ground, eds. Post and Molendijk, 119-143, here 131. Stengs claims that the ritualised space of the roadside memorials (for road traffic victims) is also a politicised space, as relatives place the victim in the political context of protest against ongoing traffic disasters.
} 


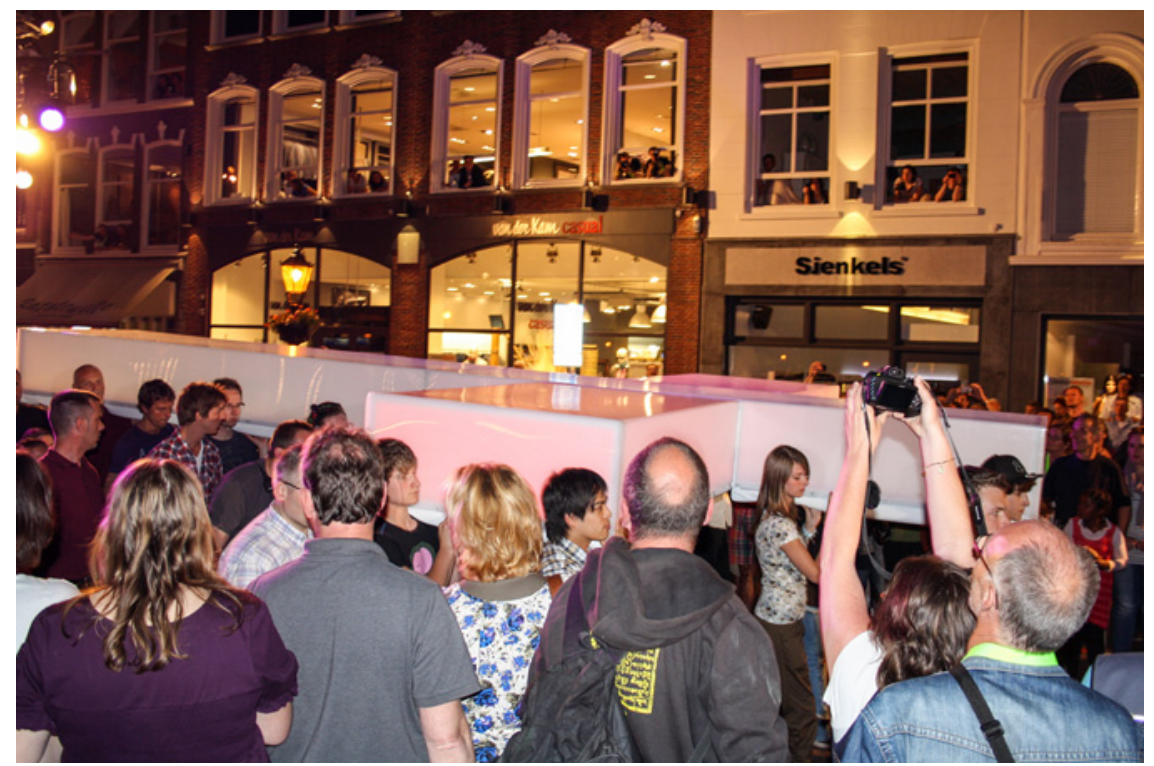

FIGURE 8 The procession with the cross passing the audience in the Market square in Gouda, while making its way to the main stage PHOTO: (C) HIJME STOFFELS

as it is a spatial practice, it is a social practice which, as we will demonstrate below, has formed part of the conflicts that The Passion has generated.

\section{Musical Space}

Thirdly, the performance, besides being a physical and ritual space, through its characteristic use of pop songs, turns Gouda and its market square into a musical space. ${ }^{23}$ By choosing Dutch-language hits, the biblical story of Jesus' last days and hours is integrated into a Dutch context. On the one hand, the songs are part of the story; on the other, they reinforce the Dutch décor by which the performance is surrounded. However, when regarded as spatial practice,

23 Cf. Barry Truax, Acoustic communication (Norwood: Ablex, 1984); Raymond Murray Schafer, The soundscape: our sonic environment and the tuning of the world (Rochester: Destiny Books, 1993); Peter Sloterdijk, In hetzelfde schuitje: proeve van een hyperpolitiek (Amsterdam: Arbeiderspers, 1997); Marcel Cobussen, "Verkenningen van/in een muzikale ruimte. Over Peter Sloterdijk en Edwin van der Heide”, in Interakta \#5. Grootstedelijke reflecties. Over kunst en openbare ruimte, eds. H.A.F. Oosterling and S. Thissen (Rotterdam: Faculty of Philosophy, Erasmus University, 2002), 208-211; Martijn Oosterbaan, "Sonic Supremacy. Sound, Space and Charisma in a Favela in Rio de Janeiro", Critique of Anthropology 29, no. 1 (2009), 81-104. 
the music has a more significant effect: it stakes out the space, not only in a physical, but also in a symbolic sense. While it is true that music has a certain inherent boundlessness, there are nevertheless differences in the impact that music has in relation to the position of the listener. Music tends to have a greater impact on those closer to the source, closer to the performer. This is related in particular to the multi-sensory experience that music provides: those who are close to its source, hear, feel and see the music being performed. To those who are at more of a distance (physically on the square, or as TV viewers) there is less of a sensory appeal: the ability to feel and see the performance is diminished, the volume decreases and, in the case of $\mathrm{TV}$ viewers, becomes dependent on the person with the remote control. The experience of musical space through the body therefore marks out different locations: ranging from zones in which the musical experience is more or less intense, to parts of the city that fall outside of the musical space of the performance. However, the musical space can also be interpreted in a symbolic way: the Dutch-language hits can invite people to engage in The Passion as a performance, but may also 'scare them off' or deter them.

Thus far, we have not elaborated on how the performance of The Passion, as well as receiving approval from many, is also sometimes met with rejection. The physical, ritual, and musical aspects of this spatial practice has sometimes generated conflicts, caused by the fact that The Passion as a performance simultaneously serves quite different interests: evangelisation, promotion of the city of Gouda, and entertainment. The Passion not only tells the story of Jesus' last days and hours, but also tells of a culture that employs and explores a new way of searching for its religious roots, with all the attendant clashes that go with this. Viewed from this perspective, The Passion represents a social space: an area in which 'fans' and 'haters', insiders and outsiders, do battle.

\section{Mental Space: Appropriation}

The spatial practice of The Passion not only comprises the physical, ritual and musical space, but attribution and appropriation are also part of spatial practices. Mindful of the processes of transfer and transformation of ritual repertoire that we described in Chapters 1 and 2, 'secular' pop songs are appropriated in a new context. This context is formed not only by the frame of the biblical narrative, but also by the context of the performance, which is moulded by the singers playing their role, by the musicians, the images, the marketplace of Gouda, and the procession of the cross, etc. For the participants (audience, performers) the performance is a multi-sensory experience. The connotations attached to each person's experience of the performance are an important aspect of the appropriation process, as it is influenced by previous experiences. 
The work of French linguist Gilles Fauconnier can help to gain more insight into how this appropriation works. Fauconnier's theory of how meaning is constructed in language is based on the faculties of the human mind and sheds light on how the structure and use of our language is able to point to so-called 'mental spaces' (separate domains of referential structure) and conceptual projection. ${ }^{24}$ We will, therefore, briefly discuss some of the relevant mental spaces that can be blended into peoples' experience and appropriation of The Passion. First, there is the pop scene and people's personal (positive or negative) experiences with pop music. Appropriation of The Passion depends partly, we presume, on peoples' familiarity with the pop songs that are used in the performance. Second, the biblical narrative not only provides the frame to which the pop songs are transferred, but also a mental space in itself. As with the pop songs, peoples' familiarity with the biblical narrative also influences their appropriation of The Passion. A third point of reference is the genre of the musical and, in particular, the musical Jesus Christ Superstar, composed by Andrew Lloyd Webber and Tim Rice, which was performed for the first time in 1971 on Broadway. A film adaptation of Jesus Christ Superstar was released in 1973 and became very popular among the Dutch, and, in 2005, a Dutchlanguage performance of the musical took place. A fourth mental space is that of the many movies about the passion of Jesus Christ, which have been released over the years, one of the most recent being Mel Gibson's The Passion of Christ (2004). Fifthly, there is a wide tradition of passion plays throughout the world, but also in the Netherlands in the southern village of Tegelen where they have been performed since 1931 and take place quinquennially. Sixthly, there is a strong tradition of musical passion performances in the Netherlands. These are highly popular in Dutch culture, especially Bach's St Matthew Passion, but also his St John Passion, both of which are frequently performed in churches and concert halls during Lent. The Dutch love Bach..$^{25}$ Since the year 2000 , a revival seems to have taken place, as a significant number of new passions have been composed and performed, and, judging by attendance, seem to be highly appreciated. ${ }^{26}$

\footnotetext{
24 Gilles Fauconnier, Mental Spaces. Aspects of Meaning Construction in Natural Language (Cambridge: Cambridge University Press, 2010).

25 Emiel Wennekes, "Wie zingt nu eigenlijk de paashaas? Nederland en de MatthäusPassion", in De geheimen van de Matthäus-passion. Ambacht en mystiek van een meesterwerk, ed. Pieter Dirksen (Amsterdam: Balans, 2010), 105-123.

26 Mirella Klomp, "Joseph \& Jesus”; Mirella Klomp, "Passio - Compassio. J.S. Bach's Passions Transformed into a Passion Transcending Christianity", in Retrieving Compassion: Global Ethics, Human Dignity, and the Compassionate God, eds. Frits de Lange and Julie Claassens
} 


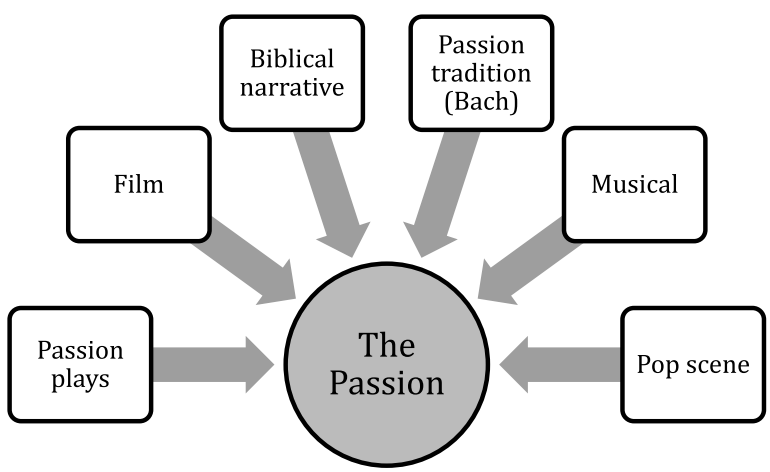

FIGURE 9 Mental spaces that may influence the appropriation of The Passion

The appropriation and appreciation of pop songs as part of the performance of The Passion depends, at least partly, on the successful integration of diverse mental spaces into a single blend. If participants in the audience or on stage, either individually or as a group, cannot or will not accept the popsongs as a way of telling the story of Jesus' last days in a new, contemporary format, a conflict may arise: the use of pop songs in the context of a biblical narrative will make The Passion 'contested ground' in several ways, as we will see.

\section{Contested Ground and Multidimensional Space}

From the very first performance in Gouda in 2011 onwards, The Passion has sparked sharp debate between people who are enthusiastic about the phenomenon and those who disapprove. Local authorities, for example, were happy to be able to put Gouda on the map in 2011 in (what they considered to be) a positive fashion. Prior to the performance, protests began to surface from various different directions. On social media, one person tweeted "Performance of The Passion in Gouda (...) is insulting and contempt of the Gospel", and an inhabitant of the city followed this with a complaint about the noise and the crowds and was worried whether she would be able to even park her car that

(Eugene OR:Wipf and Stock, 2018), 187-202; Mirella Klomp, "Ecclesioscapes: interpreting gatherings around Christian music in and outside the church. The Dutch case of the 'Sing Along Matthäuspassion'", in Studying Congregational Music. Key Issues, Methods, and Theoretical Perspectives, eds. Andrew Mall, Jeffers Engelhardt and Monique Ingalls (Abingdon: Routledge, forthcoming). 
afternoon. ${ }^{27}$ After the performance, the mood on the square (at least among the audience around me) seemed generally appreciative. However, in 2014, a Dutch journalist and TV presenter who had been an atheist since childhood ${ }^{28}$ was unmistakably negative on Twitter, and called the event 'religious kitsch': "The Passion is a violation of, of, of so many things, it makes you awfully sick \#relikitsch". ${ }^{29}$ Indeed, as Schippers has stated, sacred space is contested space. During our research in the field, we encountered several instances where the interpretation and evaluation of The Passion in the market square was not only diverse, but also conflicting and, at least for the duration of this spatial practice, turned the space into contested ground. ${ }^{30}$ Post is another theorist who highlights this potential for conflict, asserting that, in the triad of place, ritual and sacrality, space and place not only interact, but also entail contestations. Exploring the complexity, layered character, ambiguity and ambivalences of spatial practices, he sets out four dimensions, which we will touch upon in the following discussion of three examples.

\section{The Market Square: Object of City Marketing versus Business Interest} The producers of The Passion chose the city of Gouda because it is a mediumsized city, where the performance of a passion like this would have a large impact and get a lot of attention, both on a local and, through live TV coverage, on a national scale. The city council then adopted the project in order to raise the profile of the city. ${ }^{31}$ Some 1.5 years before the event, the city had been in the national news for a few weeks because of riots and misbehaviour by some of its youth. After Gouda was approached, the city council decided to seize upon the chance to market the city and the opportunity to use The Passion in order to show that Gouda is a beautiful historical city where nice events

27 Jan-Willem (@papavanlara), “Uitvoering 'The Passion' in Gouda van EO en RKK is schoffering en minachting van het evangelie. HC zondag 35 v/a 98", Twitter, April 21, 2011.

28 Teun van de Keuken, Puur en eerlijk: de boodschappen van een keurmeester (Amsterdam: Thomas Rap, 2014).

29 Tweet by Teun van de Keuken @teunvandekeuken, "De Passion is een verkrachting van, van, van zoveel dingen, dat je er hartstikke misselijk van wordt. \#relikitsch", April 15, 2014, 4.38 p.m.

30 Martijn Oosterbaan, in an interesting article, demonstrated how the soundscape forms an important element of the public space of the favela and reveals many of its power relations, thus contributing to a multi-sensory conceptualisation of place. Oosterbaan, "Sonic Supremacy". His argument seems less relevant in the case of The Passion, as this performance was not the spatial practice of one clearly defined group, but more an interplay of various parties and individuals.

31 Information on the city (council) in this sub-section is taken from an interview I did with Jacoline Stout and Andrea Olieman, municipality of Gouda, February 2012. 
are able to take place. As it turned out, the event did indeed generate an influx of tourists. It also had an 'empowering' effect on the city's inhabitants, local organisations and entrepreneurs proving that they could bring about something good. It thus had an unexpected positive influence external to the passion performance itself. As philosopher Liliana Gómez has discussed, the performance element of festivities and celebrations can often play a cohesive role in urban societies. ${ }^{32}$

Nonetheless, not all were happy with the performance of this mega-event in the physical space of this particular market square, as can be seen from the legal proceedings that took place only two days before the actual event. On Monday, when the organisation had started building the stage, one of the entrepreneurs of one of the shops in the market square slowly began to realize that this was going to be a huge event and discovered that the stage would physically extend to only a few meters from his shop-window. He sued the municipality for (expected) loss of income. The economic interests of the shop owner conflicted with the city council's interest in promoting the city through the performance of this Passion. The entrepreneur lost the case: consequences such as this, as well as potentially positive impacts on other occasions, were considered to be inherent in having a shop on the market square. As one of the aldermen of Gouda reportedly said: 'this time the disadvantage is yours, next time it is your neighbour's'. All entrepreneurs in the market square collectively share in what happens in 'the living room of the city'.

The spatial practices of The Passion prompted contestations in relation to the physical space of the market square, as it had to be prepared for such a huge musical performance. The contestation thus had to do with the size of the event. In the ambiguity and ambivalences of this spatial practice, we here recognize what Post calls 'sacral zoning'. Sacrality is connected with ritual, and the centre of the ritual here was the stage. "The zoning connected to ritual and liturgy brings all kinds of tensions with it, for it has to do with marking off and setting boundaries that are always under pressure", Post claims. ${ }^{33}$ In this case, the entrepreneur saw the sacred space - physically claimed by the stage - clash with the walking space of his customers. This incident demonstrates that, apart from the event taking up a physical and ritual space, it also constitutes a social space where, in this case, different interests turn out to act in explicit opposition.

\footnotetext{
32 Liliana Gómez, "The Urbanization of Society. Towards a Cultural Analysis of the Sacred in the Modern Metropolis", in The Sacred in the City, eds. Liliana Gómez and Walter van Herck (London/New York: Continuum, 2012), 31-51, here 37. 


\section{A Musical Event: Vehicle for Evangelisation or an Entertainment Show?}

The broadcasting companies EO and RKK, the two churches involved and the Dutch Bible Society intended, through The Passion, to present the gospel in modern 'clothing'. Using pop songs, contemporary language, and modern techniques, and by putting on a large-scale broadcast event live in a primetime slot, their primary aim was to reach young people, 'to give the gospel back to the street'. ${ }^{34}$ The event raised objections and critical comments from believers belonging to various churches. A month before the event was to take place in Gouda, three orthodox reformed churches, supported by the local branch of the Reformed political party SGP (Staatkundig Gereformeerde Partij), asked the city council to withdraw the license that had been granted to the organizers. They submitted a joint letter through which they communicated their objections to the Mayor and Aldermen of the city of Gouda, stating that:

The suffering, death and resurrection of our Lord Jesus Christ lie at the core of our reformed confession of faith. (...) The lived reality of being sinners before God, our personal faith that embraces the redemption through the sacrifice of Jesus Christ, and the victory over death (...) we experience these things with silent astonishment; they lead to worship and humble confession. (...) We find it repulsive that the suffering of Jesus is made the subject of an event through noisy (pop) music and filmed play-acting. The essence of the passion narrative is thus degraded to entertainment. (...) $[\mathrm{H}]$ owever beautiful our city - we consider it profoundly inappropriate to comply with this event in order to promote the city and to cooperate in its production as a partner. The suffering and death of the Lord Jesus Christ is too sacred and devote to us to serve as the basis for city promotion. ${ }^{35}$

The objections obviously concentrate both on the musical and the ritual space that The Passion creates, and, at the same time, relate to the physical space of Gouda with its situation at the tail end of the orthodox Bible belt. "These pop songs have nothing to do with the passion narrative", the chairman of SG P

34 According to Leo Fijen, then director of RKK broadcasting company (that later merged into KRO), in an interview by $\mathrm{MK}$, December 2011.

35 "Aan het College van Burgemeester en Wethouders van de gemeente Gouda", (letter of objection against The Passion), Gereformeerde Gemeente Gouda et al., obtained via http://www.nd.nl/images/library/PDF/gouda.pdf on March 22, 2012. Quotation translated by MK. 
Gouda explained in an interview, and in his opinion the event was surrounded by a lot of noise. In response to the question of why he called the music "noise", he declared that this was a matter of musical taste, but also that these songs were not pious: "The passion narrative should not be told through cheap music". ${ }^{36}$ The SGP took offence particularly at the fact that the municipal council had not bothered to inform them and the reformed churches in Gouda at an earlier stage; the council could have known that this was going to cause trouble. At the time that the aggrieved parties submitted their objections, they had not yet been informed about the procession with the cross through the city streets. Afterwards, their spokesman declared that they had considered this ritual practice objectionable as well, for similar reasons: "The suffering and death of our Lord Jesus Christ is so sacred and intense... that it must be treated with veneration, and is not something to be played with". ${ }^{37}$ The aggrieved parties clearly were not open to blending the mental space of passion plays and that of the pop scene within their appropriation and appreciation of The Passion. The mental space of the Biblical narrative to them was so exclusive and sacred that it should not be linked to other mental spaces. The council responded to these objections, saying that an event like The Passion is in keeping with a pluralist society as well as with Gouda's tolerant image. ${ }^{38}$

Precisely the same complaints were put forward by a Roman Catholic blogger, who despite coming from quite a different spiritual and ecclesial tradition, and despite an openness towards contemporary culture, reacted against several ads for The Passion, writing that:

It will be nice, I am sure. We cannot let any opportunity pass by to contextualize and present Christianity, and the church should not position itself outside of our media culture. But I have mixed feelings about this. I will not be attending. What's this, 'shops are open'? What's this, 'a nice evening in Gouda'? What this 'sparkling show'? Something wrenches my heart. The way of the cross is one of modesty. It is delicate. These are stations of the cross. Statio. Standing still, (frozen in time). No spectacle, no 'shopping with Peter' and 'Doner Kebab Judas'. It is about falling three times, a distressed mother with tears in her eyes, a desolate Jesus, 30

36 Arjan Versteeg, member of the City Council of Gouda on behalf of the SGP, interview by MK, February 23, 2012.

37 Rien Hoek, spokesman on behalf of the three reformed churches, interview by мк, March 8 , 2012. Translation by M K.

$38 \quad$ Newspaper article in Nederlands Dagblad, 18 March 2011. 
pieces of silver, and gambling over his robe. It is a crucifixion. (...) Jesus dies without cocktail nuts. ${ }^{39}$

His objections do not so much relate to the musical space created by the performance of modern pop songs within the frame of a biblical narrative, neither do they relate to the ritual space created through the performance in the square and the procession with the cross, or to the physical space of Gouda's market square. His objections appear to relate to the scale of this mega-event, the media campaign behind it and the promotion surrounding it. In his view, these are at odds with what he sees as the core characteristics of the crucifixion.

Whilst some of the organisations putting on the event saw The Passion as a vehicle for evangelisation, the objections voiced by individuals such as this blogger arise because of the entertainment character of the show. This ambiguity relates to what Post describes as a trend towards the relativisation of sacrality, in the sense that it becomes bound up with changing societal and cultural circumstances. In the case of the churches and the political party discussed above, that entails a connection to changing media culture; in the case of the blogger, to consumerism and informalisation. "Sacrality itself represents a program", according to Post. ${ }^{40}$ This holds both for the actualisation of Christian ritual repertoire in late-modern culture (or, what some would call, a relativisation of the sacred), and to the insistent demands of solemn rituals, which are here associated with opposition to banality of modernity, and influence of secularisation (what Post would call a 'countermovement', and Barnard 'resistance identity'41).

\section{The Separation of Church and State at Stake}

The broadcasting companies involved in The Passion have a missionary goal that they "have never been secretive" about. ${ }^{42}$ Gouda, as we have already emphasised, adopted the Passion project for reasons of city marketing. In the opinion of city officials, Eye2Eye Media has proved to be a "secular, professional production company", easy to approach in an atmosphere of open exchange;

39 Blog by Eric van den Berg, "The Passion Gouda: Jezus sterft zonder borrelnootjes". April 21, 2011. https://www.mediakathedraal.nl/the-passion-gouda-jezus-sterft-zonder -borrelnootjes/. Last accessed May 10, 2020. Cf. Chapter 1 for further explanation.

40 Cf. Post, "Complexity and conflict", 241-265, 247.

41 Cf. Post, "Complexity and conflict", 247-248. Cf. Barnard, Cilliers and Wepener, Worship in the Network Culture, 13; 74-76.

42 Reinder van Dijk, RKк broadcasting company, interview by Mк, March 2012. Also cf. the aim of production company Eye2Eye Media that I mentioned in Chapter 1. 
in Gouda this was able to create a certain atmosphere of trust that the city could participate in an event that would not turn out to be an explicitly religious happening. This was important because of the separation of church and state, which the city council took very seriously. Because of this separation, by their own account, Gouda decided to engage not on the level of content, but solely in facilitating the event:

Our task really was to facilitate and to supply and to make available: the square; the town hall; the people; the cooperation with the police; safety. That was our part. (...) Helping a particular target group or a religious group - that would really be impossible. If you do that you are crossing the line. ${ }^{43}$

The separation of church and state was a matter of serious concern for the city of Gouda. It came as no surprise, therefore, that the city council was not amused when, in the course of the media campaign unleashed by the broadcasting companies prior to the performance, The Passion was portrayed as a missionary event.

And all of a sudden, Syb (who was to play the role of Jesus, MK) had his coming out as a believer. (...) And they started to use a kind of word that I can't remember exactly, but because of that word, what it boiled down to was that The Passion was to persuade non-believers, and it became a kind of mission thing too... And then we thought: no! (...) Eventually, our alderman brought this to the attention of the producer in an extra meeting and said that this was not the approach that we had agreed upon. It was supposed to be more open and broader. And this turned out to be very helpful. ${ }^{44}$

To the city of Gouda, the physical, musical and ritual space that would be created through the performance of The Passion was not intended to serve any kind of missionary purpose. The city council insisted that The Passion would be presented as an event open to all, not as a means to evangelize nonbelievers. The contestation here regarded the tension between imposed meaning and the open character of the event; unambiguity versus multi-diversity; 'experience the story of Jesus, who died for you too' versus 'just come and ascribe to The Passion the meaning you like', to put it bluntly. This example again

43 Stout and Olieman, interview, February 2012.

44 Stout and Olieman, interview, February 2012. 
demonstrates that The Passion was a social space where several parties fought to make their own dominant meaning heard.

The tension that arose can be related to what Post describes as the ambiguity surrounding the basic sacrality of a ritual space. ${ }^{45}$ This ambiguity relating to the basic sacrality of a place has been a theme in Christian tradition from the outset, as, according to Post, it has emphasised the encounter with God, and has always been critical of the binding of God to any single place. This is why, from the perspective of the production company and the Christian broadcasting companies, The Passion could easily be performed in the open. Yet, the market square was incontestably a place set apart for the performance, it was claimed, and, when in the preparation process the word missionary was used, and the performer in the role of Jesus was revealed as a Christian, the space was once again "reclaimed from its surroundings, (... and) maintained in its status of being separate". 46 This set apart character of the sacred space presented the city council with a problem, as they - in their own view - were not facilitating a Christian event, but an event that would contribute to the positive outlook on the city.

\section{Conclusion}

A spirituality of dwelling in late-modern societies has developed into a spirituality of seeking, and the sacred does no longer grow on trees, but is rather something to be negotiated, recognised, found, discovered, and encountered at times. ${ }^{47}$ What is considered to be sacred is dynamic; it results from processes of the attribution of meaning to, and experience of, practices and objects. As a consequence, the sacred can be found anywhere. In this chapter we discussed three examples in which different interests and meanings conflict show how The Passion in Gouda was a spatial practice that, for a period of around 90 minutes, led to the creation of a site which was simultaneously both sacred and contested. The examples demonstrate that physical, musical and ritual spaces never have simply one meaning and always have multiple meanings ascribed to them. These meanings are fluid; they come into being through spatial practice. Multiple meanings can exist side by side, but sometimes also lead to contestation. The Passion in Gouda is an example of a spatial practice that,

45 Post, "Complexity and conflict", 244-245.

46 Post, "Complexity and conflict", 244.

47 Cf. Wuthnow, After Heaven, 3-4. 
for a while, turned the market square into a site which was ambiguous and multi-dimensional but nonetheless also sacred. Whether and, if so, how God may be found in ambiguous and multi-dimensional spaces and practices in a post-Christian, post-secular context, is a question worthy of further theological reflection. 